\title{
Criticism of "Kırgınlar Evi” in Relation to Cultural Adaptations
}

\author{
“Kırgınlar Evi” İsimli Oyunun Kültürel Uyarlamalar Açısından Bir Eleştirisi
}

\section{Özkan KIRMIZI*}

\begin{abstract}
The purpose of this study is to carry out a criticique of Sevgi Sanlı's translation of "Heartbreak House", "Kirginlar Evi" in Turkish, in relation to the cultural adaptations that are applied by the translator. The initial section of the study focuses on the related literature in an attempt to expound what drama translation is and what the inherent difficulties in drama translation are. In the second section, there is the actual analysis of the translation. In the criticism section, the construct of performability was the guiding principle throughout the study. Within the concept of performability, “cultural adaptations” in the play were extensively analyzed. As a result, it was found the translator successfully handled the translation.
\end{abstract}

Keywords: Drama translation, translation criticism, performability, cultural adaptation

Özet: Bu çalışmanın amacı Türkçe'ye "Kırgınlar Evi” olarak çevrilen ve özgün ismi "Heartbreak House” olan oyunun çevirisini kültürel uyarlamalar açısından eleştirmektedir. Çalışmanın ilk kısmı oyun çevirisi ve oyun çevirisiyle ilgili zorlukları açıklamaktadır. Çalışmanın ikinci kısmında oyunun eleştirisi yapılmaktadır. Oyunun eleştirisinde sahnelenebilirlik kavramınından faydalanılmıştır. Sahnelenebilirlik kavramı bağlamında oyunda geçen "kültürel uyarlamalar" detaylı bir biçimde analiz edilmiştir. Sonuç olarak çevirmenin tercümeyi oldukça başarılı bir şekilde gerçekleştirdiği görülmektedir.

Anahtar Sözcükler: Oyun çevirisi, çeviri eleştirisi, sahnelenebilirlik, kültürel uyarlamalar

Drama texts are not translated in the way other literary texts are translated. The first reason for this is that drama texts are somehow incomplete in the sense that they are to be completed when they are performed on the stage. Here the translator is faced with a fundamental question; whether to translate the drama text like any other literary text or to translate it in its function. According to theatre semiotics, linguistic content is only one of the elements that convey the meaning. Anne Ubersfeld (in Bassnett, 1991) indicates that theatre texts are closely linked to performance and they are not easy to take apart (Bassnett, 1991).

Bassnett also tries to analyze inherent difficulties of drama translation as follows: “...a theatre text exists in a dialectical relationship with the performance of that text. The two texts written and performed-are coexistent and inseparable, and it is in this relationship that the paradox for the translator lies” (1985, 87). Broadly speaking, the analysis here will mainly focus on whether linguistics information is conveyed and whether the translated text of the play is proper for a Turkish audience.

\section{Drama Translation}

Translation of drama texts does not seem to have received due theoretical attention compared to other literary texts, partially due to the fact that drama texts have two purposes, namely, to be

\footnotetext{
* PhD., Başkent Üniversitesi, İngilizce Hazırlık Birimi, ozkankirmizi@gmail.com
} 
read and to be performed. It is interesting to note that the spatial or gestural (Bassnett, 1991) features, although inherent features of drama, were not substantiated until the twentieth century. The term "gestic nature" of the drama text should not be underestimated in that different cultures use different sign systems, ranging from body language to paralinguistic and kinesic signs. Thus, the undertaking of translating a drama text may turn out to be a "superhuman activity" (Bassnett, 1991) because all drama texts include gestic features that are to be performed, rather than translated. In the same vein, Pavis (1992) argues that drama translation led to a paradigm shift in that it is no longer performed solely on the basis of semantic equivalence; rather, it involves the appropriation of one text by another. Pavis is trying to explain that something that is unrealized (that is, not performed) in the source language is hard to evaluate totally, pleading that this can, under ideal circumstances, occur during the real performance.

Drama translation only came to the attention of translation scholars during the 1980s and 1990s. One of the most important developments that brought drama translation into focus was Ortrun Zuber's book entitled, the Languages of Theatre: Problems in the Translation and Transposition of Drama, which concentrated on the problems of theatre translation. And this was the first book written in this area.

In terms of drama translation, Rose (1981) makes the distinction between audience-adapted and textually-autonomous translations. Levefere (1977) distinguishes between reader-oriented and text-oriented translations. We can understand that drama translation can go between paradigms. They can either address the audience or the original text to a greater or lesser degree.

Broader terms for drama translation are iterated by Gostand (1980) as follows:

- one language to another (difficulties of idioms, slang, tone, style, irony, word play or puns)

- one culture to another (customs, assumptions, attitudes)

- one age/period to another

- one dramatic style to another (realistic or naturalistic to expressionistic or surrealist)

- one medium to another (stage play to radio, TV or films)

- $\quad$ printed page to stage

- emotion/concept to happening

- verbal to non-verbal presentation

As it can be understood from the list, translation of drama texts involves a wide range of cases where translators have to sort out translation problems and resort more to creative translation so as to render the written page into another language or culture, and ultimately onto the stage.

\section{Adaptation in Drama Translation}

Adaptation is the most studied strategy in drama translation. Baker $(2009,4)$ states that "adaptation is sometimes regarded as a form of translation which is characteristic of particular genres, most notably drama". According to Brisset $(1989,10)$, adaptation in drama translation can be viewed as a 'reterritorialization' of the original work for the audience of the new version. Similarly, the process of adaptation was seen as 'naturalizing' by Santoyo $(1989,104)$ 'naturalizing' the play for a new cultural environment, and accordingly the aim is to achieve the same effect that the work originally had. The driving force for the present study comes from Billington's (1984) notion of 'creative rewrites' to describe adaptation, which is conceived as most successful in the case of more robust comedies. Since "Hearbreak House" is a comedy, it is important that adaptations play an important role in the translation.

\section{Criticism in Drama Translation}

It was stated that Bassnett $(1985,87)$ characterized drama texts and the difficulties in their 
translations as a paradox in which the translator faces a number of problem solving situations. The word to underline here is 'paradox'. Due to the inherent difficulties of drama texts, namely the dual function of drama texts and the existence of paralinguistic features in them, drama translators undertake a dual responsibility where they are entitled to solve the paradox. The paradox is explained by Aaltonen (1993) as follows: "the translator makes conscious or unconscious choices, which are not accidental by nature, but imposed on her/him by the system to which the completed translation will belong as an element" Similarly, she further asserts that a play script's primary function is to communicate its intended meaning clearly to the target audience and while doing this some sort of deviations in the norms and conventions of the original text may happen. Therefore, it is clear that the most important aspect of drama translation is its being understandable to the target audience.

Defined as the need for fluent speech rhythms in the target text, one discussion that is vital for drama translation is the concept of performability, which denotes drama texts are pieces of written material that are intended to be performed, and which constitutes one part of the gestic nature of drama texts. According to Bessnatte, the term 'performability' is in fact the root of many of the problems that are peculiar to the translation of drama. A performable drama text is a speakable drama text, embodying rhythm of speech, easy graspability, and simplicity of pronunciation. Although the concept of performability is not favored within drama translation literature, the term is going to be used here to denote whether the text is translated in a way that lends itself to its actual performance.

\section{The Criticism of the Play}

The criticism of the play boils down to the criticism of cultural adaptations in the play. As an extension, this study also dwells on how the translator solved problems in the translation. The last part lists the parts where the translator included extra elements which are thought to be redundant.

\section{Cultural Adaptations}

Billington (1984) emphasises that if adaptations can be achieved in the form of 'creative rewrites', they will bring about the desired outcomes, especially in the case of comedies. Adaptations may take different forms. Withing the scope of this study, we will focus on cultural adaptations. Due to the humor included in the play, there is a quantity of cultural elements in the original text. They had to be adapted to the target culture in order to render the play understandable. Examples of cultural adaptations are given below.

Sorry to wake you up, miss, I'm sure; but you are a stranger to me.

Sizi uyandırdım küçük bayan; ama siz kimsiniz kuzum.

The use of 'kuzum' in similar situations continues throughout the translation. This is a good example of 'acculturation'. Similar situations follow throughout the translation. Some are at word level like 'kuzum' or 'totoşum' and some are at idiomatic level.

Examples of acculturations are as follows:

- The captain: had she no friends, no parent is to warn her against my daughter's invitations?

Kaptan: Eşi dostu, hısmı akrabası yok mu? Kimse kızımın davetleri için kulağını bükmemiş mi?

- The captain: ... no doubt he became rich...

Kaptan: Artık yükünü tutmuştur.

- The captain: ...she married him.

Kaptan: ...kız ona vardı.

- Nurse Guinnes: .... and very glad you should be to see... 
Nurse Guinnes: ...bayram etmelisiniz...

- Nurse Guinnes: ... his mind wanders from one thing to another.

Nurse Guinnes: ...aklının terazisi bozuldu.

- Captain Shotover: Another person has arrived and wants a room. Man about town, well dressed, fifty.

Kaptan: Biri daha geldi. İki dirhem bir çekirdek, feleğin çemberinden geçmiş, su içinde ellilik var.

- Lady Utterword: nobody at home to receive anybody.

Ev sahiplerini koydunsa bul.

- Lady Utterword: I have a mind to go away without another word.

Şeytan diyor ki, al başını git gözünün gördüğü yere.

- Mrs. Hushabye: she is going to marry a perfect hog of a millionaire for the sake of her father, who is as poor as a church mouse.

Zügürt babasının hatırı için domuz gibi bir milyonerle evlenecek.

- Lady Utterword: You ought to kiss me....

Beni öpmen yakışık alır.

- Lady Utterword: Indeed I shall do nothing of the sort

Lady Utterword: Allah esirgesin!

- Mazzini: her taste is on the graver, solider side.

Mazzini: Olgunlar, ağırbaşlılar daha çok zevkini okşar.

- Mrs. Hushabye: graver, solider taste, indeed!

Mrs. Hushabye: Olgunlar ağır başlılar zevkini okşarmış, sevsinler.

- Ellie: certainly, not now!

Ellie: Artık geçmiş ola!

- Mrs. Hushabye: very well, I will tell your father.

Mrs. Hushabye: Şimdi babana söylerim, görürsün gününü.

- Mrs. Hushabye: why isn't your father rich?

Mrs. Hushabye: Söyle bakalım, baban niçin meteliğe kurşun atıyor.

- Mrs. Hushabye: Pulling the devil by the tail.

Mrs. Hushabye: Kolay mı kör şeytana meydan okumak.

- Ellie: I don't mean that he lent it to him, or that he invested it in his business.

Ellie: Ödünç filan değil, düpedüz bağışladı.

- Mrs. Hushabye: This was when I was a child.

Mrs. Hushabye: Ben daha bacak kadar çocukken.

- Ellie: That was all; for at the end of two years my father was utterly ruined.

Ellie: Topu topu iki y1l. Sonunda babam sermayeyi kediye yükletti.

- Captain Shotover: stuff!

Captain Shotover: Söylediği lafa bak!

- Mrs. Hushabye: bit off more than he could chew.

Mrs. Hushabye: Başından büyük işlere girişmiş

- Mrs. Hushabye: and when did the Boss develop the tender passion?

Mrs. Hushabye: Patron cenapları size ne zaman abay1 yakt1.

- Mrs. Hushabye: you may have drifted into it; but you will bounce out of it, my pettikins, if I am to do anything with it.

Mrs. Hushabye: Nişan mişan anlamam. Anlaşma bozulacak canikom, hem de tezelden. Hele ben kolları sıvayayım da gör.

- Mrs. Hushabye: ...especially old people

Mrs. Hushabye: ...özellikle geçkince adamlara

- Ellie: of course not! 
Ellie: Ne münasebet.

- Mrs. Hushabye: ...I know too well what liars are like. Somebody has really told you all this.

Mrs. Hushabye: Yalancıların ciğerini okurum ben. Birisi bütün bu martavalları yutturmuş sana.

- Mrs. Hushabye: You will find it far less trouble to let papa have his own way than try to explain.

Mrs. Hushabye: Babama meram anlatmak zordur. Suyuna göre gidiverin en iyisi.

- Ellie: Not in the least. I am quite cured.

Ellie: Vız gelir. Şifa buldum bile.

- Captain Shotover: then you also make a hundred thousand a year, hey?

Kaptan Shotover: Öyleyse sen de doğrultuyorsundur yüz bini.

- Mrs. Hushabye: how can you sit there telling me such lies?

Mrs. Hushabye: Elli, gözümün içine baka baka nasıl uyduruyorsun bu kuyruklu yalanları.

- The captain: That is how I have come to think my absent daughter Ariadne a perfect fiend so do not try to ingratiate yourself here by impersonating her. (57)

Kaptan: Ben de cehennemin bir bucağındaki kızım Ariadne'yi tam bir iblis diye düşünmeye alıştım. Onun için kendinizi Ariadne diye yutturmaya kalkmayın. Boşuna zahmet, gözümüze giremezsiniz.

- Lady Utterword: ...pagan philosophers...

Lady Utterword: ...zindık filozoflar...

Normally, the word 'pagan' means 'putperestlik' in Turkish, but it would not be proper to translate it as 'putperest'. The translator solved the problem with creativity.

- The captain: ...or it would be impossible to endure them.

Başka türlü çekilmez mübarekler.

This one seems to be a good example of concretization. The word 'mübarekler' was preferred by the translator in the place of 'them' in the original text. This word might have been included in order to stress the general theme of the play, in which people have some sort of dislike to each other.

- Lady Utterword: what comfort? What sense is there in having servants with no manners?

Lady Utterword: Dil bir karış kadında. Böyle yol yordam bilmeyen hizmetçileri tutmak neye yarar sanki?

- "My worthy friend, we haven't got twenty pounds".

"ne yapalım iki gözüm, yok bizde o kadar para".

Here "we haven't got twenty pounds" is translated as "yok biz de o kadar para". This is also a case of neutralization because the phrase would make no sense if it had been translated as "ben de yirmi paund/lira yok".

The Turkish translation of the lines above does not seem to be equal to the original text. The translator seems to have paraphrased it in order to convey the meaning more clearly. However, it could also have been translated as "bu ne rahatlk?" which could have given the desired meaning. The translator seems to have gone to great lengths in order to ensure concretization because there is an extra statement here which does not exist in the original text. It is "boşuna zahmet, gözümüze giremezsiniz”.

- The captain: I'm neglecting my social duties.

Kaptan: Aa, kalaballk ediyorum.

Here also there is another case of approaching the translation from a pragmatic viewpoint. The translator indicated here the pragmatic meaning rather than the surface meaning of the utterance. 
Already, the statement "I'm neglecting my social duties" would be meaningless if it had been translated as "sosyal görevlerimi ihmal ediyorum". The translator seems to have solved a problem of translation here with dexterity.

- Ellie: .... and yet tells lies about things that he never did and that never happened?

Ellie: Sıra övünmeye gelince yalanın bini bir para.

- Mrs. Hushabye: You will find it far less trouble to let papa have his own way than try to explain.

Mrs. Hushabye: Babama meram anlatmak zordur. Suyuna göre gidiverin en iyisi.

- Mangan: that is the sort of man I am; and there will be a better understanding between us when you make up your mind to that, Captain.

Mangan: İşte karşınızda böyle bir adam var. Bunu unutmayın yoksa külahları değişiriz.

- Captain Shotover: I know nothing more than I have seen in her eyes. She will break it off. Take my advice: marry a West Indian negress: they make excellent wives. I was married to one myself for two years.

Kaptan: Bilmem yalnız gözlerinde birşeyle okudum. Bence, hiç hatır gönül dinlemez bozar bu işi. Beni dinlersen batı Hint adalarından bir zenci kadın al. Çok iyi karı olurlar. Ben denemiştim gençliğimde. İki yıl gül gibi geçindik.

In the analysis above, we see that the translator did her best in order to acculturate most of the language items, be it words or idioms, for better understandability.

\section{Solving Problems in Translation}

In the play there are a number of parts that pose difficulties on the part of the translator and would do the same to the audience if they were translated in the way they are given in the original text. However, the translator seems to have handled such parts with dexterity and solved problems so that these difficult parts are more understandable and more speakable. Some of them are given below:

- Lady Utterword: ...You may think because I am a Shotover and that I am a Bohemian, because we are all so horribly Bohemian. But I am not. I hate and loathe Bohemianism. No child brought up in a strict puritian household ever suffered from puritianism as I suffered from our Bohemianism.

Lady Utturword: ...Bu aileden olduğum için belki beni de mezhebi geniş biri sanırsınız. Her biri kendi havasındadır bizimkilerin, kimse kurallara aldırmaz. Ama ben bu başıboşluktan nefret ederim. Dar kafalı, bağnaz ailelerin çocukları benim şu bohemlikten çektiğimi çekmemiştir.

- Lady Utterword: ...careless woman...

Lady Utterword: .... Sallapati bir kadın...

- Hector: You are neither a Bohemian woman nor a Puritan woman. You are a dangerous woman.

Hector: Siz ne şusunuz, ne busunuz, düpedüz baştan çıkarıcı bir kadınsınız.

It can be seen that the translator preferred 'başıboşluk' for the term 'bohemianism'. The translator avoided using the term 'bohemianism' at first. This may be for fear that the word 'bohemianism' would not be understood by the target audience. We can understand this from the fact that the word 'bohemlik' takes place three lines later when the meaning of the word 'bohemianism' seems to have been clarified by the context. In the same way, the line "You are neither a Bohemian woman nor a Puritan woman" was translated as "Siz ne şusunuz, ne busunuz". This is also a good example of solving a problem.

- Lady Utterword: on the contrary, I am a safe woman.

Lady Utterword: Amma da yaptınız. Ben adamı baştan çıkarmam başını yere getiririm. 
Here the translator added a phrase in order to empower meaning. However, even for the general atmosphere of the play, there does not seem to be a need for such a thing. Normally, it would be possible to translate the utterance as "ben aksine namusluyum"

- Captain Shotover: An adventurous life. But what does it end in? Respectability. A ladylike daughter. The language and appearance of a city missionary. Let it be a warning to all of you.

Kaptan Shotover: İpten kazıktan kurtulmuş bir herif. Ama sonuna bakın. Efendiden bir adam olmuş bayağı. Hanım hanımcık bir kızı var. Şunun konuşmasına kılık kıyafetine bakan papaz sanır keratayı. Bu hepinize ders olsun.

In the example above, "an adventurous life" becomes "ipten kazıktan kurtulmuş bir herif" and the question "what does it end in?" was turned into affirmative as "ama sonuna bakin". These treatments pave the way for better comprehensibility of the play on the part of a Turkish audience.

- Lady Utterword: I will not be ignored and pretended to be somebody else.

Lady Utterword: Buna gelemem işte. Beni tanımazdan geliyor. Yetti artık!

In terms of syntactic features, the translator broke the original utterance into three chunks for better speakability. She seems to have done a good job because translating the utterance in conformity with its original syntactic structure would bring out an incomprehensible line.

- Lady Utterword: I certainly am Addy; and I don't think I can be so changed that you would not have recognized me if you had any real affection for me. And Papa didn't think of me even worth mentioning!

Lady Utterword: Ne sandın ya? Elbet Eddy'yim. Beni gerçekten sevseydin bir bakışta tanırdın. Artık o kadar da değişmedim ya. Eh aşk olsun babama! Beni adam yerine koyup geldiğimi söylememiş bile.

Here there is one extra statement in the target text, which is "eh aşk olsun babama!" performability. The whole statement could also have been translated as "beni ilk gördügü̈nde taniyamayacağın kadar kadar değiştiğimi düşünmüyorum". However, this could have been too long an utterance for a theater line. And the line "Papa did not even think of me worth mentioning!" is translated as "babam beni adam yerine koyup..." This one is a good way of translating the given utterance.

"But one of them married a numskull. The other a liar wed". translated as

“Mankafayla baş göz oldu küçügü. Yalancılar şahına vardı, öbür kaçık”.

In these lines, there seems to be some amount of sarcasm and the words the translator used reflect the Captain's anger.

- Lady Utterword: oh, let's prosecute him and have done with him. I have conscience, too, I hope; ...

Lady Utterword: Ben olsam sana günahımı vermem. En iyisi cezalandıralım bunu. Ben de vicdan sahibiyim bugüne bugün.

In these lines, the original form of the utterance is hard to understand and would be meaningless if translated word by word. The translator paraphrased the utterance to fit it into one that is speakable.

“Mangan's Christian name was Alfred” translated as “Mangan'in ismi Alfred'miş".

In this line the translator left out the word "Christian" because that would make no sense for the Turkish audience. This is a case of neutralization and was proper. 
I fell over him in the dark: and I'm a pretty tidy weight.

Karanlıkta üstüne ylkıllvermişim. Eh, vücutta hürmetlice.

These two lines merit attention in view of the fact that there seems to be a special reason why the phrase "Eh, vücutta hürmetlice" was preferred instead of an ordinary phrase like, say "bende epeyce sisismanım". This can attributed to the fact that the play was written for the purpose of criticizing the contemporary political situation of Europe. Considering the touch of 'comedy' in the play, translating the phrase "I'm a pretty tidy weight" as "Eh, vücutta hürmetlice" can be justified. below.

Other examples where the translator used creative translation to solve problems are given

"He is madder than usual" translated as "sanki büsbütün aklını oynatmış".

"bloated capitalist" translated as "para babast".

- Mangan: what a dinner! I don't call it a dinner: I call it a meal

Mangan: Ne yemek doğrusu, ağza tat, boğaza feryat! Dişimin kovuğuna bile gitmedi.

- Mangan: Do you think I will be made a convenience of like this?

Mangan: Ne sanıyorsunuz? Bu işe alet olur muyum ben? O göz var mı bende? (64)

- Mangan: Oh, this is a crazy house. Or else I'm going clean off my chump.

Mangan: Aman Allahım, burası ev değil tımarhane. Yoksa ben mi keçileri kaçırıyorum?

- I should say that he won't have a dog's chance against Elli.

Ama bana kalırsa Ellie, onu parmağında oynatır.

- Mangan: she wants both.

Bu kız hem dedigim dedik, hem çaldığım düdük diyor

- The Burglar: I am too old to be giv a hiding, lady. Send for the police and have done with it.

It's only just and right you should. (117)

- Hırsız: Çok yaşlıyım. Döverseniz kalıbı dinlendiririm, Alimallah! En iyisi, çağırın polisi, olsun bitsin. Yerden göge kadar hakkınız var, efendim. (90)

- You know the sort of life you and me had led.

Sen de ben de az $\mathrm{m} ı$ naneler yedik gençliğimizde.

- There are two sets in the family: the thinking Dunns and the drinking Dunns.

Ailenin iki kolu vardır. Bir kafa ütüleyenler, bir de kafayı tütsüleyenler.

- The Burglar: I don't set up to be better than my fellow-creatures, and never did, as you well know, Captain. But what I do is innocent and pious. I enquire about for houses where the right sort of people live.

Hırsız: Ben haddimi bilirim Kaptan. Ele güne üstünlük taslamam. Tanırsın beni a canım, öyle herze yer miyim? Ama çok temiz bir iş tuttum ahir ömrümde. Efendiden insanların yaşadığı evleri gözüne kestiriyorum.

- Hector: and as she has all the Shotover fascination, there is plenty of competition for the job, eh?

Hector: Kadında, Shotover'lardaki o şeytan tüyü bulunduguna göre bu işin gönüllüsü çoktur değil mi?

- Lady Utterword: well, go on. What were you going to call me? An infernal what? Which unpleasant animal is it to be this time?

Lady Utterword: Söyle söyle! İçinde kalmasın! Bu defa ne olacağız bakalım? Cehennem cadısı mı, yoksa aşağılık bir hayvan $\mathrm{m}$ ?

\section{The Rewriter "par excellence"}

This part concerns issues that are purely Turkified or in Turkish form 'Türkçe Söylenmiş' in Can Yücel's terms. Can Yücel's notion of “Türkçe Söylemek" can be likened to "acculturations” in a 
sense. The parts below are examples of such cases. It must, however, be noted that there are other examples throughout the play. But these ones are the most eye-catching and hence they were selected by the author.

- Lady Utterword: I have had to grow old, like other people.

Lady Utterword: Ne yapalım yaş kemale erdi.

This way of translating the given utterance sounds a little of forcing the case because the translator could have translated the line as "herkes gibi ben de yaşlandım" or "insanlar yaşlaniyor". There was no need to insert another idiom here in view of the fact that the translation is fraught with idioms some of which do not seem to be necessary. Moreover, the meaning signaled by the statement "I have had to grow old, like other people" does not indicate that now that she is old she has to go about according to her age. The point is only to show that a lot of time has passed since the captain and his daughter saw each other. In short, it seems that there was no need to translate the statement by means of another idiom here.

- But business is business; and I ruined him as a matter of business.

Ama iş iştir. İş icabı yere serdim babanızı. İş bilenin kılıç kuşananın.

Here there is an extra utterance. The last sentence does not exist in the original text.

- I don't mind dropping a little money to start the process, I took your father's measure.

Çarkı döndürmek için biraz para dökmekten kaçınmam. Aza demişler nereye, "çoğun yanına" demiş. Babanızı şöyle bir tarttım.

In these lines, "to start the process" could have meant something else somewhere else but for a drama translation "çarkı döndürmek" seems to be one of the best choices. It perfectly fits the situation.

\section{Conclusion}

Cultural adaptations seem to have been one of the most widely used constructs in this translation. The translator used local equivalents for almost all of the linguistics items, either at word or idiomatic level, in order to render the play to the stage perfectly and its acting smoothly. However, some of them are redundant.

As is known, due to the cultural elements that may hamper understanding or expressions that are hard to understand, translators, every now and then, need to refer to creative translation in order to make these difficult parts more understandable for the target audience. The translator of the play handled the issue of creative translation carefully. Examples of these are given above under the title of "solving problems in the translation". Examples there indicate that the translator has been highly sensitive to the issue.

As a result, drawing conclusions about the translation of the play in terms of performability, it can be said that the translator seems to have given it the necessary merit. This is understandable from the accuracy of the cultural adaptation of most of the elements that would not be understood otherwise by a Turkish audience. For the sake of ensuring performability, the translator can be said to have done a good job. In addition, as for one of the sub-categories of the construct of performability, Aksoy (2002) states that the theater play must let actors or actresses breathe by proper time allocation between utterances. Sevgi Sanlı seems to have addressed this issues properly. Sentences in this translation are of reasonable length and thus make it possible to breathe in between utterances.

Rose (1981) makes the distinction between audience-adapted and textually-autonomous translations. Levefere (1977) distinguishes between reader-oriented and text-oriented translations. The application of this distinction to the translation would make it clear that the present translation 
of the play is of an audience adapted nature, or, in Levefere's terms reader-oriented. This is clear from the acculturations and neutralization the translator applied. Therefore, it is easyer the target audience for to understand, that it is a Turkish audience.

We can say that what guided the translator was primarily the drive to make the text as understandable as possible. That she ensured by resorting to frequent acculturations of certain forms that would be otherwise meaningless, neutralizations, and breaking longer utterances into manageable chunks. In short, we can say that Sevgi Sanlı translated the play quite to the point, watching most of the elements that were needed to make the play understandable to a Turkish audience.

The criticism made here is only based on these elements in the absence of the data that could have been collected from the actual performance of the translation. From the viewpoint of theater semioticians play texts are inextricably linked to their performance. They view linguistic elements is only one part of the semiotic systems that make up the theatritical event (Marineti, 2005). Therefore, a full analysis would be possible only after seeing the play on the stage.

\section{REFERENCES}

Aaltonen, S. (1993). Rewriting the exotic: The manipulation of otherness in translated drama. Ed. Catriona, Picken. Proceedings of XIII FIT World Congress, Institute of Translation and Interpreting, 26-33. London.

Aaltonen, S. (2000). Time-sharing on stage. Drama translation in theatre and society. Clevedon: Multilingual Matters.

Aksoy, B. N. (2002). Geçmişten günümüze yazın çevirisi. Ankara: İmge Kitabevi.

Baker, M., \& Saldanha, G. (2009). Routledge encyclopedia of translation studies. Abington: Routledge.

Bassnett, S. (1985). Ways through the labyrinth: Strategies and methods for translating theatre texts. Ed. Theo, Hermans. The Manipulation of Literature London: Studies in Literary Translation Croom Helm.

Bassnett, S. (1991). Translating for the theatre: The case against performability. Traduction, Terminologie, Rédaction, 4, 1, 99-111.

Billington, M. (1984). Villains of the piece. Guardian, 9 November.

Brisset, A. (1989). In search of a target language. Target, 1(1), 10-27.

Erten, A. (1998). Kültürden kültüre oyun çevirisi: Keşanlı Ali destanı. Çeviri Bilim ve Uygulamaları Semineri Bildirileri Ankara: Bizim Büro.

Gostand, R. (1980). Verbal and non-verbal communication: Drama as translation. Ed. Zuber, O. The Language of Theate: Problems in the Translation and Transposition of Drama, 1-9. Oxford: Pergamon Press.

Levefere, A. (1977). Translating literature: The German tradition. Assen: Van Gorcum.

Marinetti, C. (2005). The limits of the play text: Translating comedy. New Voices in Translation Studies, $1,31-42$.

Meta, J. C. (2002). Journal des traducteurs. Meta: Translators' Journal, 47, 1, 51-57.

Pavis, P. (1992). Theatre at the crossroads of culture. London: Routledge.

Riera, J. B. (2007). The non-verbal in drama translation: Estudios Ingleses de la Universidad Complutense, $15,119-137$.

Rose, M. G. (1981) Translation spectrum. Albany: State University of New York.

Santoyo, J. C. (1989). Traducciones y adaptaciones teatrales: ensayo de una tipología. Cuardernos de Teatro Clasico, 4, 96-107.

Shaw, B. (1919). Heartbreak House. Harmonsworth: Penguin Books.

Shaw, B. (1990). Kirgınlar evi. İstanbul: Milli Eğitim Basımevi.

Suh, J. C. (2002). Compounding issues on the translation of drama/theatre texts. Meta: Translators' Journal, $47,1,51-57$. 